\title{
26. HYDROGEOCHEMISTRY, ODP LEG 110: AN OVERVIEW ${ }^{1}$
}

\author{
Joris M. Gieskes, ${ }^{2}$ Peter Vrolijk, ${ }^{3}$ and Gerard Blanc ${ }^{4}$
}

\begin{abstract}
Drilling of the northern Barbados accretionary complex transect during Leg 110 of the Ocean Drilling Program provided a unique opportunity to study the effects of sedimentary thickening, overthrusting, and faulting on the evolution of the chemical composition of interstitial waters. The production of low-chloride fluids farther in the complex has enabled evaluation of the main pathways of fluid expulsion from the complex. These are (1) along faults in the accretionary prism itself and (2) along the décollement and through underlying sandstones. In the latter case, methane anomalies, presumably caused by methane production as a result of thermal decomposition of organic matter farther into the complex, accompany the chloride anomalies. Major cation distributions $\left(\mathrm{Ca}^{2+}, \mathrm{Mg}^{2+}, \mathrm{K}^{+}, \mathrm{Na}^{+}\right)$are primarily affected by alteration of volcanic ash and exchange with formation waters in underlying basement rocks. However, as a result of tectonic activity in the complex, exchange with the overlying ocean is diminished and concentration-decreases in $\mathrm{Mg}^{2+}, \mathrm{SO}_{4}{ }^{2-}$, and $\mathrm{K}^{+}$become larger in an arcward direction. Major cation distributions rule out the importance of pervasive advection through the sediments, thus confirming that the main pathways for fluid expulsion are along faults, the décollement, and underlying sandstones.
\end{abstract}

\section{INTRODUCTION}

The expulsion of fluid as a result of compactive processes associated with the consolidation of sediments in accretionary prisms has been shown to be important by various authors (Bray and Karig, 1985, 1986, 1988; Fowler et al., 1985; Moore and Biju-Duval, 1984). Recently, direct evidence for such fluid expulsion has been obtained from the discovery of biological communities associated with fluid venting at the seafloor, both off the coast of Oregon-Washington (Kulm et al., 1986; Rittger et al., 1987) and in the Japan Trench and Nankai Trough (Boulegue et al., 1987; Le Pichon et al., 1987; Swinbanks, 1985). The hydrogeologic system must be well understood if a more fundamental understanding of how accretionary prisms evolve is to be obtained.

The geometry and rates of fluid flow depend on the permeability structure of accretionary prisms, which in turn is a function of the lithology and structural geology. In the case of the northern Barbados accretionary complex transect (Fig. 1), drilled during Leg 78A of the Deep Sea Drilling Project (DSDP) and Leg 110 of the Ocean Drilling Program (ODP), the sediments are dominated by fine-grained hemipelagic and pelagic sediments (Moore and Biju-Duval, 1984; Mascle, Moore, et al., 1988). In this area, fluid expulsion appears to occur principally along faults (Cloos, 1984) that show increased fracture permeability (Moore, Mascle, Taylor et al., 1987). In this paper we summarize the geochemical evidence on the interstitial waters obtained during Legs $78 \mathrm{~A}$ and 110 , which serves to set limitations on attempts to model the hydrological aspects of fluid expulsion. Special attention is given to the various geochemical and physical processes that affect the chemical composition of the interstitial waters.

\section{SITE DESCRIPTION}

Detailed lithologic description of the drill sites can be found elsewhere (Biju-Duval, Moore, et al., 1984; Mascle, Moore, et

\footnotetext{
${ }^{1}$ Mascle, A., Moore, J. C., et al., 1990. Proc. ODP, Sci. Results, 110: College Station, TX (Ocean Drilling Program).

2 Scripps Institution of Oceanography, La Jolla, CA 92093. 48109 .

3 Department of Geological Sciences, University of Michigan, Ann Arbor, MI

${ }^{4}$ Department of Geology, University Louis Pasteur, Strasbourg 67084 France.
}

al., 1988), and only the salient features that affect our discussions are summarized here. The lithostratigraphic information is presented in Figure 2. The following important features should be noted:

1. The development of a zone of "future décollement" in the biogenic silica-rich early Miocene sediments in the oceanic reference Site 672 (190-220 mbsf);

2. The penetration, for the first time, of the zone of décollement in Site 671 (500-520 mbsf), thus enabling an evaluation of the importance of the décollement as a path of fluid flow out of the accretionary prism;

3. The occurrence of important faulting and overthrusting only a few kilometers arcward of the toe of the accretionary prism (Sites 676, 541, 671);

4. The extensive secondary faulting and folding in the upper few hundreds of meters of the sediment column in Sites 673 and 674;

5. The progressive decrease in porosities of the sediment column in an arcward direction;

6. The occurrence of extensive sand layers in the OligoceneEocene sections of the sediment column below the décollement at Sites 671 and 672;

7. The ubiquitous presence of volcanic ash in the Pleistocene-Pliocene sediments of all sites;

8. The strong variability in the sediment accumulation rates of the Pleistocene-Pliocene sediments.

All the above features must be taken into consideration in the evaluation of the processes that affect the chemical composition of the interstitial waters in this accretionary complex. In the following we first discuss the geochemical evidence for fluid flow in this section of the Barbados accretionary complex, followed by a discussion of additional processes that control the chemistry of the interstitial waters.

\section{MAJOR CONSTITUENTS OF INTERSTITIAL WATERS}

\section{Chloride and Methane}

Among the main features of the interstitial water data were the discovery of substantial decreases in dissolved chloride and small but measurable increases in methane, especially in zones 


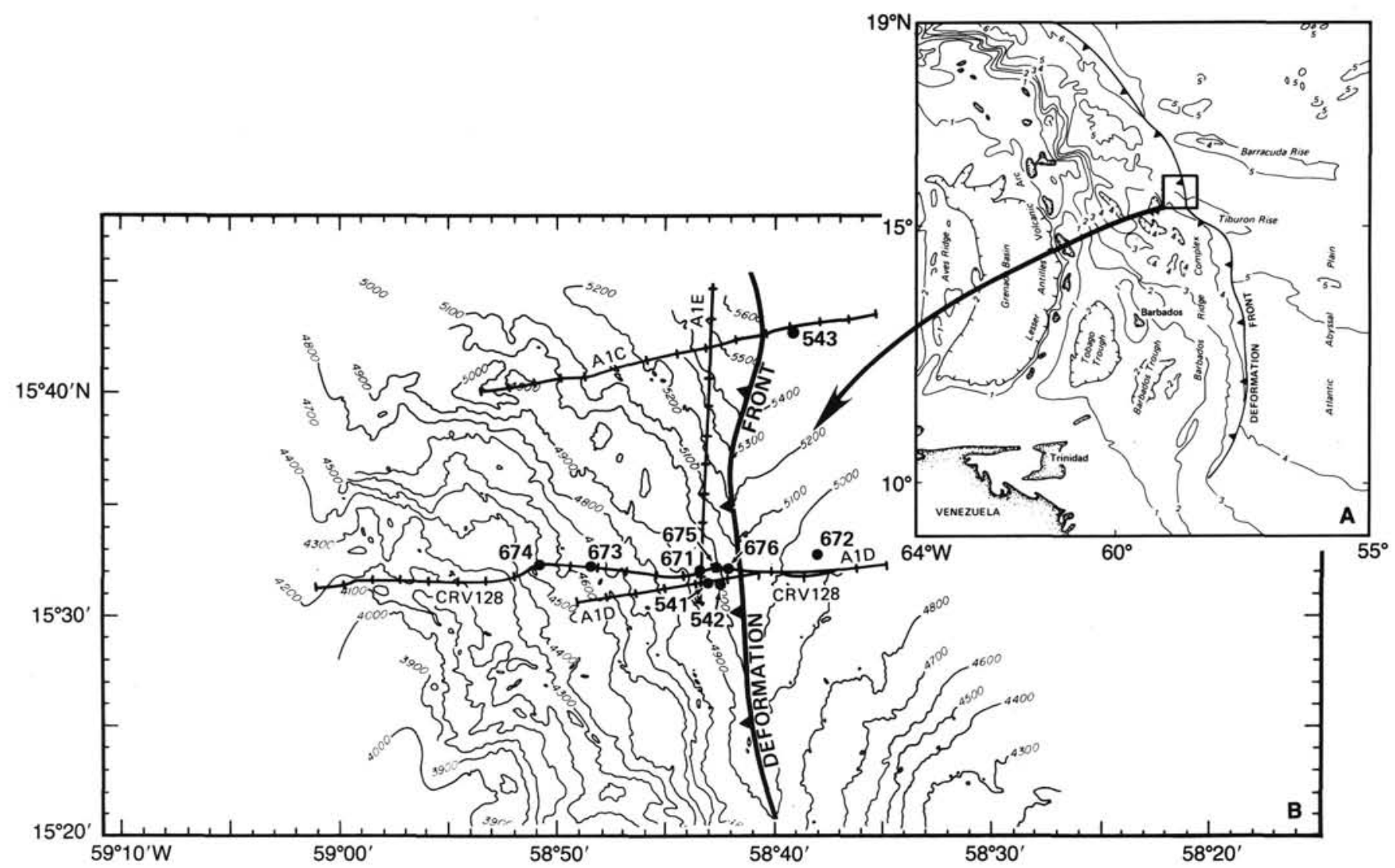

Figure 1. Location map for Leg 110 and Leg 78A drill sites. Inset shows the regional geography of the lesser Antilles island arc and the Barbados Ridge.

that show evidence for recent tectonic activity (Moore, Mascle, et al., 1987; Blanc et al., 1988; Gieskes et al., 1988). This phenomenon is demonstrated in Figure 3 for Sites 671, 672, and 674.

In Site 671 a distinct minimum in chloride and a maximum in methane is associated with the zone of décollement, although low chloride concentrations are also associated with faults or zones with scaly fabrics above the décollement. In addition, it appears that low chloride and elevated methane concentrations occur with the underlying sandstones, though no reliable data exist on the latter. In the oceanic reference Site 672 a slight effect on chloride and methane is noticeable in the zone of future décollement, but distinctly lower chloride concentrations occur in the underlying sandstone layers. Finally, large decreases in chloride occur in Site 674 , with minima occurring in zones of recent fault activity. The shallow chloride minimum at $\sim 30 \mathrm{mbsf}$ is also associated with anomalously high sediment temperatures, which can be understood best in terms of advective fluid flow along a fault, originating at greater depths in the complex (Fisher and Hounslow, this volume). Although intermediate chloride minima occur in Site 674, especially associated with recent faults, the chloride concentrations in Site 674 indicate a large decrease when compared with the other sites of the transect (Fig. 4). The principal implication of these observations is that low-chloride fluids must be expelled throughout the accretionary prism along fault zones, as well as along the underlying décollement and sandstone layers. Fluid movement along these horizons would explain the observed nonlinear temperature gradients and high heat flow values observed in all sites (Fisher and Hounslow, this volume). Chloride concentrations generally show gradual de- creases with depth, particularly in Site 674. This can be explained in terms of injections of low-chloride fluids along fault zones, with subsequent diffusive exchange with surrounding sediment layers.

An additional important observation is that appreciable concentrations of methane were measured in the décollement and in underlying sandstone layers, but no methane was found at Site 674. Methane production in situ in Sites 671 and 672 is unlikely, particularly because sulfate is present throughout the sampled sediments. Typically, biogenic methane production in marine sediments occurs following the depletion of sulfate and, indeed, methane consumption has often been established in zones of sulfate reduction. Note that in Site 674 no methane is observed in the deeper sediments, where sulfate is depleted (Fig. 3). The occurrence of methane may be thermogenic decomposition of organic matter at more elevated temperatures farther into the complex (Vrolijk et al., this volume). Presumably this methanogenesis is restricted to the sediments below the décollement, which show much higher organic carbon contents (Wang et al., this volume). The absence of methane in Site 674 suggests that indeed the major source of methane-enriched fluids must be from below the zone of décollement.

We conclude that fluid expulsion along the fault zones as well as along the décollement indicates that these zones are locally and periodically regions of low fluid pressure, at least relative to the source beds (Moore, Mascle, Taylor et al., 1987). Darcian flow calculations (Screaton et al., this volume; Wuthrich et al., this volume) suggest that fluid movement throughout intergrannular space would be much slower than the rate of subduction, so that flow must occur through a different mecha- 
nism, with a possible exception being the more permeable sandstones below the décollement. Syn-tectonic carbonate-filled veins are common in fault zones, occurring both along scaly surfaces and in relatively undeformed mudstone, suggesting that fault surfaces and new fractures opened during deformation, with fluid pressure near lithostatic values (Secor, 1965). Opening of hydrofractures to permit fluid flow implies that fluid flow is episodic. The suggested flow paths for fluids expelled from farther in the complex is shown in Figure 5. Details of hydrogeologic calculations are presented elsewhere (Screaton et al., this volume; Wuthrich et al., this volume).

The next problem is to explain the occurrence of low chloride concentrations. Previous studies on interstitial waters in accretionary prisms in the area of the Middle America Trench during DSDP Legs 66, 67, and 84 have revealed large decreases in the concentrations of dissolved chloride (Harrison et al., 1982; Hesse et al., 1985; Gieskes et al., 1985). In these settings, however, the observed decreases in chloride were accompanied by increases in the $\delta^{18} \mathrm{O}\left(\mathrm{H}_{2} \mathrm{O}\right)$ of the interstitial waters and could be considered as artefacts caused by the decomposition of methane hydrates during retrieval of the cores. Typically large amounts of methane-hydrates were recovered during these DSDP Legs and methane gas concentrations were high enough (i.e., above $50 \mathrm{mM}$ ) to be well into the stability field of methane hydrate (Claypool and Kaplan, 1974; Hand et al., 1974; Miller, 1974). In the Leg 110 sites, however, methane concentrations were always well below $1 \mathrm{mM}$ in Sites 672 and 671, and not detectable in Site 674. Thus if the low chloride concentrations are caused by hydrate decomposition farther into the complex, then we should expect relatively high methane concentrations unless substantial bacterial consumption of methane has occurred. South of the Leg 110 transect, sediments thicken rapidly and methane hydrates are commonly observed.

The low-chloride fluids may have formed by membrane filtration processes associated with tectonic dewatering. During membrane filtration, ions will be retained preferentially in the formation and relatively fresh water will be released. Such processes have often been invoked to explain observed low salinities in over-pressurized zones sandwiched between sediment layers containing oil field brines (Fertl, 1976; Hanshaw and Coplen, 1973; Fritz and Marine, 1983; Marine and Fritz, 1981). Manheim and Horn (1968) and Manheim (1970) doubt that sufficient pressure gradients exist to support the membrane filtration process (see also Hanor, 1983). On the other hand, in the case of forced fluid flow along the décollement zone and fault zones it may be possible that such conditions are fulfilled. An argument against membrane filtration as a cause for the dilution of the salt content of the fluids is that small increases in $\delta^{18} \mathrm{O}\left(\mathrm{H}_{2} \mathrm{O}\right)$ are observed to be associated with decreased chloride concentrations, at least as a first approximation (Vrolijk et al., this volume).

Another possibility is that freshening of interstitial waters, especially deeper in the accretionary prism, is due to the dewatering of clays (J. Schoonmaker Tribble, this volume; Vrolijk et al., this volume). At this point we prefer this explanation, although we cannot rule out a contribution of fluids from a zone of decomposed hydrates farther to the south.

\section{Other Dissolved Constituents}

In addition to the observation of anomalies in the distributions of chloride and methane, discussed in the previous section, the alteration of volcanic ash in the Pleistocene-Pliocene sediment sections is an important contributor to the observed chemical changes in pore-fluid chemistry of sediment sampled during Legs 78A and 110 (Gieskes et al., this volume). In this section we emphasize the latter process as well as the influence of basalt alteration on the interstitial water profiles.
Alteration of volcanic ash in the sediment column of many drill sites has been shown to cause depletions in magnesium and $\delta^{18} \mathrm{O}\left(\mathrm{H}_{2} \mathrm{O}\right)$, as well as the increase in calcium in the interstitial waters (Gieskes and Lawrence, 1981; Gieskes et al., 1987). The occurrence of ash layers is presented in Figure 6. The distribution of alkalinity $\left(\mathrm{HCO}_{3}{ }^{-}\right)$, calcium, magnesium, $\delta^{18} \mathrm{O}\left(\mathrm{H}_{2} \mathrm{O}\right)$, $\mathrm{Na} / \mathrm{Cl}$, and potassium in the interstitial water columns of Holes $672 \mathrm{~A}, 671 \mathrm{~B}$, and $674 \mathrm{~A}$ are presented in Figures 7, 8, and 9. The sodium/chloride $(\mathrm{Na} / \mathrm{Cl})$ ratio was chosen to reduce the influence of chloride concentration variations. It is evident that in the volcanic ash-rich sections, minima in alkalinity, minima in magnesium, and decreases in potassium indicate uptake in these sediments, with relatively minor effects on the $\delta^{18} \mathrm{O}$ and calcium profiles, especially in Site 672.

Specific sinks for magnesium (smectites?) and potassium are difficult to identify in these sediments, and bulk chemical analyses of the sediments do not allow a quantitative estimate of the magnesium and potassium uptake because of the relatively high background concentrations of these elements (Wang et al., this volume). On the other hand, the depth distribution of the ${ }^{87} \mathrm{Sr} /$ ${ }^{86} \mathrm{Sr}$ ratio of dissolved strontium (Fig. 10) clearly indicates that these ratios are well below contemporary ${ }^{87} \mathrm{Sr} /{ }^{86} \mathrm{Sr}$ seawater values (De Paolo and Ingram, 1985; Hess et al., 1986; Palmer and Elderfield, 1985; Gieskes et al., 1986, 1987), mainly as a result of isotopic exchange with the less radiogenic strontium in volcanic material. Because of the relatively low concentrations of strontium in the interstitial waters (Gieskes et al., this volume) the ${ }^{87} \mathrm{Sr} /{ }^{86} \mathrm{Sr}$ ratio is a very sensitive indicator of volcanic matter alteration.

A second important feature, especially evident in Sites 671 and 672 , is the progressive increase with depth in dissolved calcium, especially below the décollement. This increase is associated with decreases in magnesium in the deeper parts of the sediment column, but especially also in sodium. This observation suggests that the source of calcium-enriched fluids is at great depths, presumably in the underlying formation waters of the basalts of Layer 2 of the oceanic crust. In the latter, relatively early depletion in magnesium is followed by the uptake of sodium during alteration of basaltic rocks (McDuff, 1981; Lawrence and Gieskes, 1981). To unravel the various processes that contribute to the observed changes in calcium and magnesium, it is worthwhile to consider a correlation diagram between these two constituents (Fig. 11; Gieskes et al., this volume). Several features are evident from this diagram. First, a strong linear correlation exists between changes in calcium and magnesium $(\Delta \mathrm{Ca} / \Delta \mathrm{Mg} \approx-0.78)$ in the volcanic ash-rich sediments, with lower magnesium and higher calcium concentrations occurring in the sites characterized by high sedimentation rates. In the zone of décollement and slightly below this zone (Sites 672 and 671) magnesium concentrations, at least in Sites 671 and 675, show slight decreases (cf., Gieskes et al., this volume and Fig. $8)$. The increase in magnesium is mostly due to the Mg-minimum created above the décollement as a result of ash alteration reactions. The minimum in calcium, however, may simply be due to dilution as in the case of the chloride profiles. Below the décollement zone the data show sharp increases in calcium and a small, but distinct, decrease in magnesium with a linear correlation and a slope $\Delta \mathrm{Ca} / \Delta \mathrm{Mg} \approx-4.5$. If these observations are due to exchange between the sediment and the formation fluids of underlying oceanic crust (McDuff, 1981; Lawrence and Gieskes, 1981), then upon extrapolation of magnesium concentrations to zero, calcium concentrations would rise to $\sim 225 \mathrm{mM}$ and the sodium concentrations would decrease to $\sim 180 \mathrm{mM}$. If, in the underlying basement rocks, calcium concentrations would continue to increase (Gieskes, 1983), a total depletion in sodium could occur in these formation waters, thus yielding an almost 

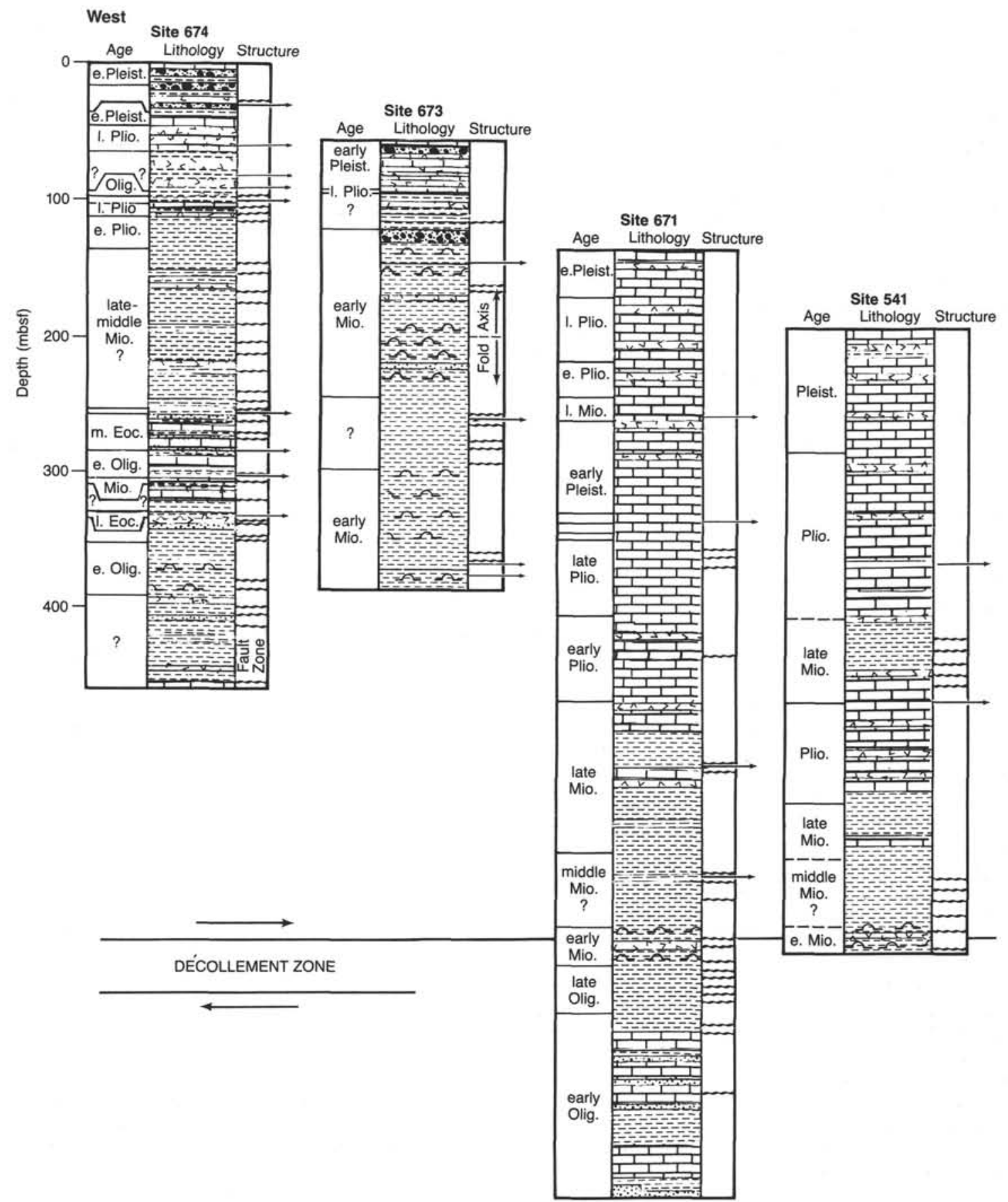

Figure 2. Lithostratigraphy of Leg 110 and 78A transects.

pure calcium chloride brine. Though the correlation diagram does allow one to distinguish various potential contributing processes, a primary result is that the diagram indicates the nonsteady-state nature of the various concentration-depth profiles.

Two more processes must be considered to more fully understand the nature of the dissolved calcium and magnesium pro- files. This can best be discussed on the basis of a compilation of the dissolved magnesium profiles along the Leg 78A/110 transect (Fig. 12). First, sedimentation rates are important. Increased sedimentation rates cause a diminished diffusive exchange with the overlying ocean (Gieskes and Johnston, 1984). Thus, even with reaction rates of similar magnitude, increased depletions in 


Structure
Thrust fault
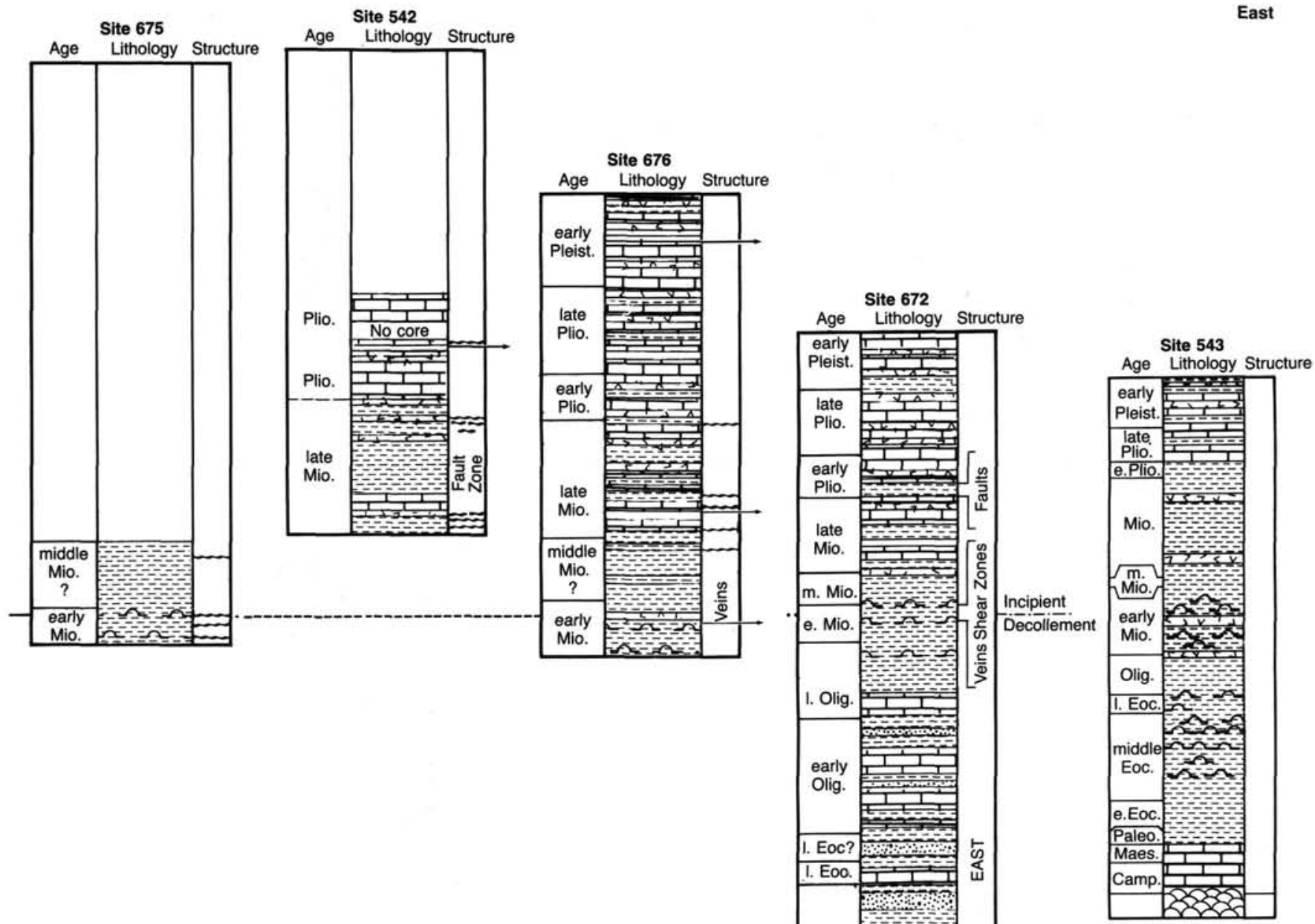

Figure 2 (continued).

magnesium will result if sedimentation rates are higher. This is typically the case for Site 541, which has a much thicker Pleistocene-Pliocene section than the other sites of the transect. In addition, thrust faulting and folding (as well as advection of fluids along fault zones) may play an important role. This is well demonstrated in Figure 8 (Site 671), where a relatively large deple- tion occurs in magnesium (and $\delta^{18} \mathrm{O}$ ) in the early Pleistocene sediments of the underthrusted sediments below $128 \mathrm{mbsf}$ (cf., Fig. 2). This can be understood in terms of increased reaction rates of volcanic material in these underthrusted sediments as a result of increased temperatures, as well as in terms of diffusive exchange with the overlying sediments. Similarly, folding pro- 

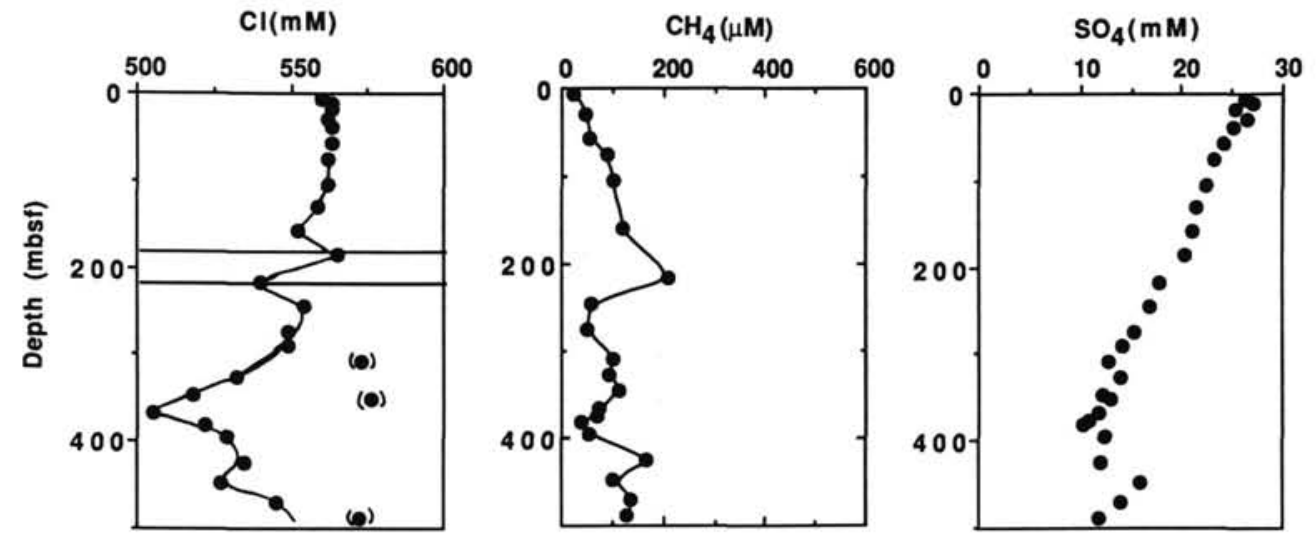

$672 \mathrm{~A}$
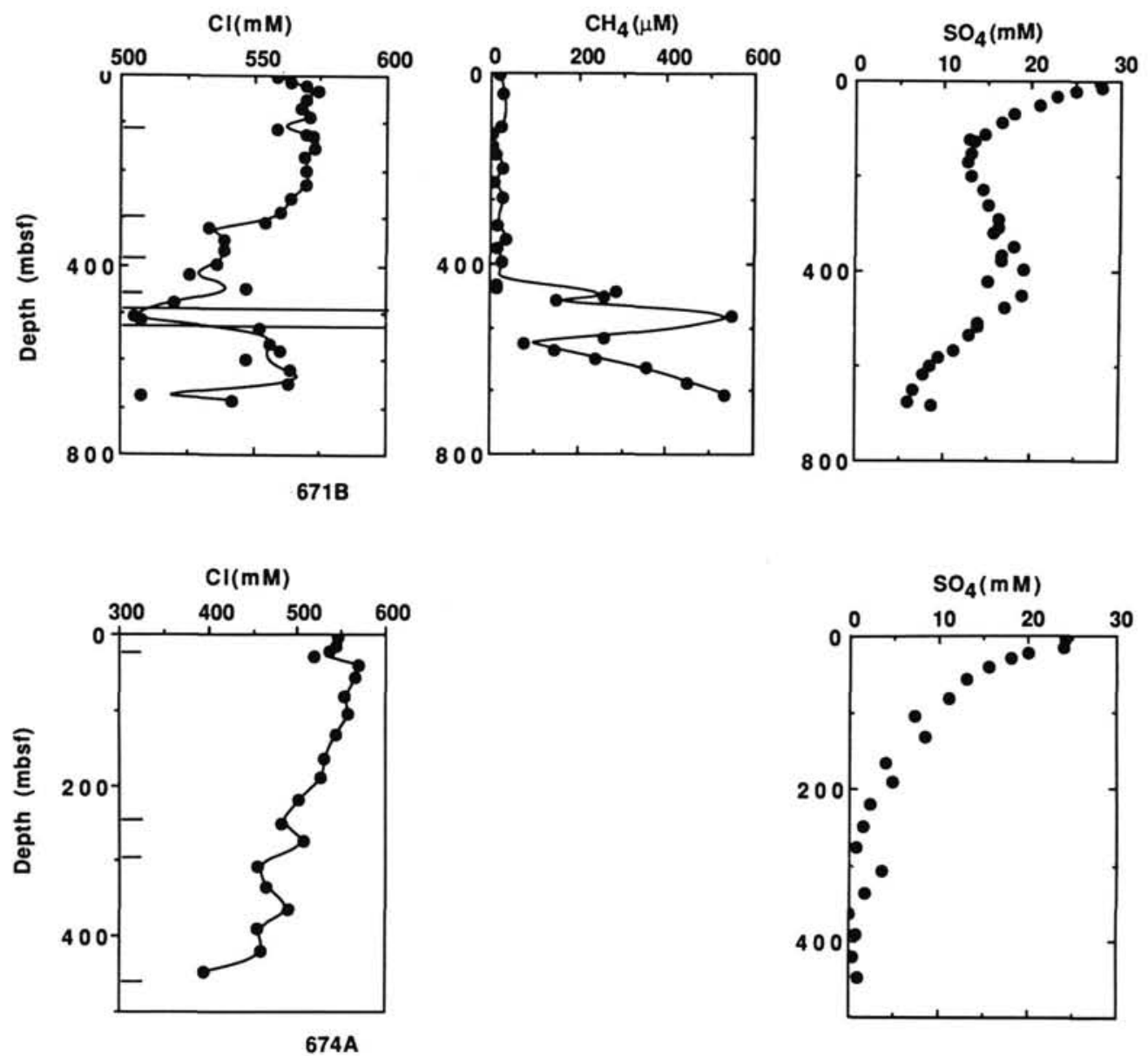

Figure 3. Chloride, methane, and sulfate concentration-depth profiles for Sites 672, 671, and 674. Small horizontal bars indicate fault zones or zones with scaly fabrics; complete horizontal bars delineate zone of décollement. Site $672 \mathrm{Cl}$ data in brackets are thought to be spurious (Gieskes et al., this volume).

cesses (e.g., Site 674) can lead to greater magnesium depletions at relatively shallow depth as a result of emplacement of more magnesium-depleted sediments from greater depths into younger sediment sections. A combination of these various processes typically leads to the progressive depletion in magnesium arcward in the accretionary prism (Fig. 12). Similar arguments can be made for progressive depletions in sulfate and potassium. Hitherto we have not attempted a comprehensive model to test this semi-quantitative reasoning.
An examination of the dissolved magnesium profiles of Figure 12 suggests that uniform upward advection of pore fluids through the sediment column is negligible, particularly because smooth gradients exist over at least a 100 -m depth range from the surface. Considerations involving conservative advective and diffusive mass transport suggests that upward advection rates must have been lower than $0.03 \mathrm{~cm} / \mathrm{yr}$ under these conditions. This observation confirms the conclusion that dewatering in the northern Barbados accretionary prism must occur mostly along 


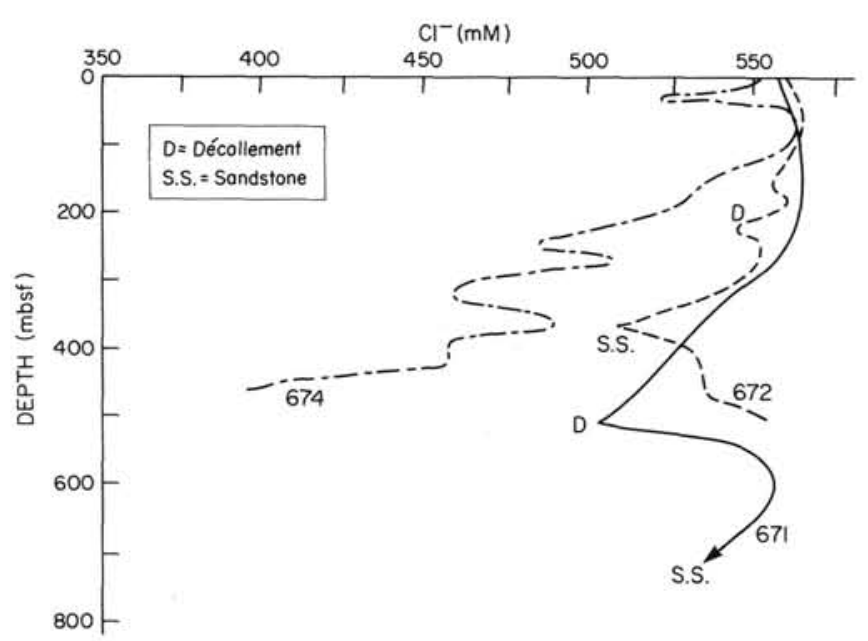

Figure 4. Outline of concentration-depth profiles for dissolved chloride in Sites 672, 671, and 674 .

fault zones, the zone of décollement, and the underlying sandstone layers.

\section{Oxygen Isotopes}

A major feature of the oxygen isotope distributions is that an apparent sink for $\mathrm{H}_{2}{ }^{18} \mathrm{O}$ is located at great depth in Sites 671 and 672 (Figs. 7 and 8). Vrolijk et al. (this volume) have shown that close correlation exists between dissolved calcium increases and $\delta^{18} \mathrm{O}\left(\mathrm{H}_{2} \mathrm{O}\right)$ decreases, especially at Site 672. This correlation is similar to that established by Lawrence and Gieskes (1981), who demonstrated that the source for high calcium and low $\delta^{18} \mathrm{O}\left(\mathrm{H}_{2} \mathrm{O}\right)$ fluids was in the formation waters of Layer 2 . This, therefore, confirms the conclusion reached from the discussion of the calcium and $\mathrm{Na} / \mathrm{Cl}$ profiles that the deeper signals in calcium, magnesium, $\delta^{18} \mathrm{O}\left(\mathrm{H}_{2} \mathrm{O}\right)$ and $\mathrm{Na} / \mathrm{Cl}$ are related to exchange with basement. Unfortunately, Site 672 was terminated well short of basement.

Reactions in the upper, volcanic ash-rich, sediment column of Site 672 involving the alteration of volcanic ash have only a minor effect on the concentration gradients of calcium and on $\delta^{18} \mathrm{O}\left(\mathrm{H}_{2} \mathrm{O}\right)$. In Site 671 , however, alteration of volcanic ash in the underthrust section below $128 \mathrm{mbsf}$ has a more noticeable effect on calcium and $\delta^{18} \mathrm{O}\left(\mathrm{H}_{2} \mathrm{O}\right)$. Of particular interest, however, is the large scatter in $\delta^{18} \mathrm{O}\left(\mathrm{H}_{2} \mathrm{O}\right)$, especially in the section between 300 mbsf and the décollement, i.e., the zone in which decreases in chloride have been observed. Similarly, the hydrogen isotope composition of the interstitial water in this sediment section shows a great degree of scatter (Vrolijk et al., this volume). Though there is no clear correlation between anomalies in chlorides and those in $\delta^{18} \mathrm{O}$ and $\delta \mathrm{D}$ in this "zone of distributed deformation" above the décollement zone of Site 671 (Vrolijk et al., this volume; Gieskes et al., unpublished data), it appears that a complex set of processes involving the expulsion of "anomalous" fluids from deeper in the complex is associated with the scatter in $\delta^{18} \mathrm{O}$ (and $\delta \mathrm{D}$ ) in Site 671.

Whereas in Site 674 a sharp decrease occurs in $\delta^{18} \mathrm{O}\left(\mathrm{H}_{2} \mathrm{O}\right)$ in the upper $200 \mathrm{~m}$, below this depth higher values are observed. This may be associated with the fluids of low chloride content that are characteristic in the lower sections of Hole 674A.

\section{SUMMARY AND CONCLUSIONS}

The detailed program of study of the interstitial water composition of the various drill sites of Leg 110 has allowed an evaluation of several important aspects that are associated with the hydrogeology of the initial process of accretion in the northern Barbados accretionary complex:

1. Expulsion of low-chloride fluids with elevated concentrations occurs along the zone of décollement and through underlying sandstones;

2. Farther onto the complex, continued depletion in chloride concentrations characterizes the pore fluids, but no methane anomalies are observed. The processes described can be summarized in a cartoon model of the envisaged fluid flow (Fig. 5). Quantitative estimates of this fluid expulsion have been presented by Screaton et al. (this volume) and Wuthrich et al. (this volume);

3. Although low-chloride fluids have been demonstrated to have an origin deeper into the complex, the origin of these fluids remains uncertain, though dewatering of clays may play an important role;

4. Major constituents of the interstitial waters (calcium, magnesium, sodium, and potassium) as well as changes in $\delta^{18} \mathrm{O}$ $\left(\mathrm{H}_{2} \mathrm{O}\right)$ indicate that both reactions involving volcanic ash in the Pleistocene-Pliocene sediments and involving underlying basalts affect concentration-depth profiles of these constituents. Changes in chloride indicate only minor effects on these concentration profiles, but concentration gradients in the upper few hundreds of meters of the sediment column indicate that a general upward advection of fluid through the sediment column is negligible, thus emphasizing the importance of fluid expulsion along faults, the décollement, and the underlying sandstones.

\section{ACKNOWLEDGMENTS}

The authors appreciate the reviews by two anonymous reviewers. J.M.G. appreciates support through NSF Grant OCE86-13517.

\section{REFERENCES}

Blanc, G., Gieskes, J. M., Mascle, A., et al., 1988. Advection des fluides interstitiels dans les series sédimentaires du complexe d'acroution de Barbade (Leg 110 ODP). Bull. Soc. Geol. France, 4:453-460.

Biju-Duval, B., Moore, J. C., et al., 1984. Init. Repts. DSDP, 78A: Washington (U.S. Govt. Printing Office).

Boulegue, J., liayama, J. T., Charlou, J. L., and Jedwab, J., 1987. Nankai Trough, Japan Trench, and Kuril Trench: geochemistry of fluids sampled by submersible "Nautile". Earth Planet Sci. Lett., $83: 362-375$.

Bray, C. J., and Karig, D. E., 1985. Porosity of sediments in accretionary prisms and some implications for dewatering processes. J. Geophys. Res., 90:678-778.

1986. Physical properties of sediments from Nankai Trough, Deep Sea Drilling Project Leg 87A, Sites 582 and 583. In Kagami, H., Karig, D. E., et al., Init. Repts. DSDP, 87:827-842.

Claypool, G. E., and Kaplan, I. R., 1974. The origin and distribution of methane in marine sediments. In Kaplan, I. R. (Ed.), Natural Gases in Marine Sediments: Mar. Sci., 3:99-140.

Cloos, M., 1984. Landward dipping reflectors in accretionary wedges: active dewatering conduits? Geology, 12:519-522.

DePaolo, D. J., and Ingram, B. L., 1985. High-resolution stratigraphy with strontium isotopes. Science, 227:938-940.

Fertl, W. H., 1976. Abnormal Formation Pressures: Implications to Exploration, Drilling, and Oil and Gas Resources (Developments in Petroleum Science series): Amsterdam (Elsevier), 190-196.

Fowler, S. R., White, R. S., and Louden, K. E., 1985. Sediment dewatering in the Makran Accretionary Complex. Earth Planet. Sci. Lett., 75:427-438.

Fritz, S. J., and Marine, I. W., 1983. Experimental support for a predictive osmotic model of clay membranes. Geochim. Cosmochim. Acta, 47:1515-1522.

Gieskes, J. M., 1983. The chemistry of interstitial waters of deep sea sediments: interpretation of Deep Sea Drilling data. Chem. Oceanogr., 8:221-269.

Gieskes, J. M., and Johnston, K., 1984. Interstitial water studies, Leg 81. In Roberts, D. G., Schnitker, D., et al., Init Repts. DSDP, 81: 829-836. 
Gieskes, J. M., and Lawrence, J. R., 1981. Alteration of volcanic matter in deep sea sediments: evidence from the chemical composition of interstitial waters from deep sea drilling cores. Geochim. Cosmochim. Acta, 45:1687-1703.

Gieskes, J. M., Johnston, K. and Boehm, M., 1985. Appendix. Interstitial water studies, Leg 66. In von Huene, R., Aubouin, J., et al., Init. Repts. DSDP, 84:961-967.

Gieskes, J. M., Elderfield, H., and Palmer, M. R., 1986. Strontium and its isotopic composition in interstitial waters of marine carbonate sediments. Earth Planet. Sci. Lett., 77:229-235.

Gieskes, J. M., Lawrence, J. R., Perry, E. A., Grady, S. J., and Elderfield, H., 1987. Chemistry of intersititial waters and sediments in the Norwegian Sea. DSDP Leg 38. Chem. Geol., 63:143-155.

Gieskes, J. M., Blanc, G., Vrolijk, P., et al., 1988. Hydrogeochemistry in the Barbados Accretionary Complex: Leg 110 ODP. Paleogr. Paleoclimatol. Paleoecol., 71:83-96.

Hand, J. H., Katz, D. L., and Verma, V. K., 1974. Review of gas hydrates with implications for ocean sediments. In Kaplan, I. R. (Ed.), Natural gases in Marine Sediments: Mar. Sci., 3:179-194.

Hanor, J. S., 1983. Fifty years of development and evolution of subsurface sedimentary brines. In Boardman, S. J. (ed.), Revolution in Earth Sciences: Advances in the Past Half-Century: Dubuque (Kendall/Hont), 99-111.

Hanshaw, B. B., and Coplen, T. B., 1973. Ultra filtration by a compacted clay membrane. II. Sodium ion exclusion at various ionic strengths. Geochim. Cosmochim. Acta, 37:2311-2327.

Harrison, W. E., Hesse, R., and Gieskes, J. M., 1982. Relationship between sedimentary facies and interstitial water chemistry of slope, trench, and Cocos plate sites from the Middle America Trench transect, Deep Sea Drilling Project Leg 67. In Aubouin, J., von Huene, R., et al., Init. Repts. DSDP, 67:603-614.

Hess, J., Bender, M. L., and Schilling, J. G., 1986. Evolution of the ratio of strontium-87 to strontium-86 in seawater from Cretaceous to Present. Science, 231:979-984.

Hesse, R., Lebel, J., and Gieskes, J. M., 1985. Interstitial water chemistry of gas hydrate bearing sections on the Middle America Trench slope, Deep Sea Drilling Project Leg 84. In von Huene, R., Aubouin, J., et al., Init. Repts. DSDP, 84:727-737.

Kulm, L. D., Suess, E., Moore, J. C., et al., 1986. Oregon subduction zone: venting, fauna, and carbonates. Science, 231:561-566.
Lawrence, J. R., and Gieskes, J. M., 1981. Constraints on water transport and alteration in the oceanic crust from the isotopic composition of pore water. J. Geophys. Res., 86:7924-7934.

LePichon, X., Iiayama, P. et al., 1987. Nankai Trough and Zenisu Ridge: a deep-sea submersible survey. Earth Planet. Sci. Lett., 83:285-299.

Manheim, F. T., 1970. Critique of membrane filtration concepts as applied to origin of subsurface brines. AAPG Bull., 54:858.

Manheim, F. T., and Horn, M. K., 1968. Composition of deeper subsurface water along the Atlantic continental margin. Southeastern Geophys., 9:215-236.

Marine, I. W., and Fritz, S. J., 1981. Osmotic model to explain anomalous hydraulic heads. Water Resour. Res., 17:73-82.

Mascle, A., Moore, J. C., et al., 1988. Proc. ODP., Init Repts., 110: College Station, TX (Ocean Drilling Program).

McDuff, R. E., 1981. Major cation gradients in DSDP interstitial waters: the role of diffusive exchange between seawater and the upper ocean crust. Geochim. Cosmochim. Acta, 45:1705-1715.

Miller, S. L., 1974. The nature and occurrence of clathrate hydrates. In Kaplan, I.R. (Ed.), Natural gases in marine sediments. Mar. Sci., 3: 151-177.

Moore, J. C., and Biju-Duval, B., 1984. Tectonic synthesis, Deep Sea Drilling Project Leg 78A: structural evolution of off-scraped and underthrust sediments. In Biju-Duval, B., Moore, J. C., et al., Init. Repts. DSDP, 78A:601-621.

Moore, J. C., Mascle, A., Taylor, E., et al., 1987. Expulsion of fluids from depth along a subduction zone décollement horizon. Nature, 326:785-788.

Palmer, M. R., and Elderfield, H., 1985. The Sr-isotope composition of seawater over the past 75 million years. Nature, 314:526-528.

Rittger, S., Carson, B. and Suess, E., 1987. Methane derived authigenic carbonates formed by subduction induced pore water expulsion along the Oregon-Washington margin. Geol. Soc. Am. Bull., 98:147-156.

Secor, D. T., 1965. Role of fluid pressure in jointing. Am. J. Sci., 263: 633-646.

Swinbanks, D., 1985. Deep-sea clams: new find near Japan's coast. $\mathrm{Na}$ ture, 316:475.

Date of initial receipt: 8 November 1988

Date of acceptance: 11 May 1989

Ms 110B-157 
West

DEFORMATION

East
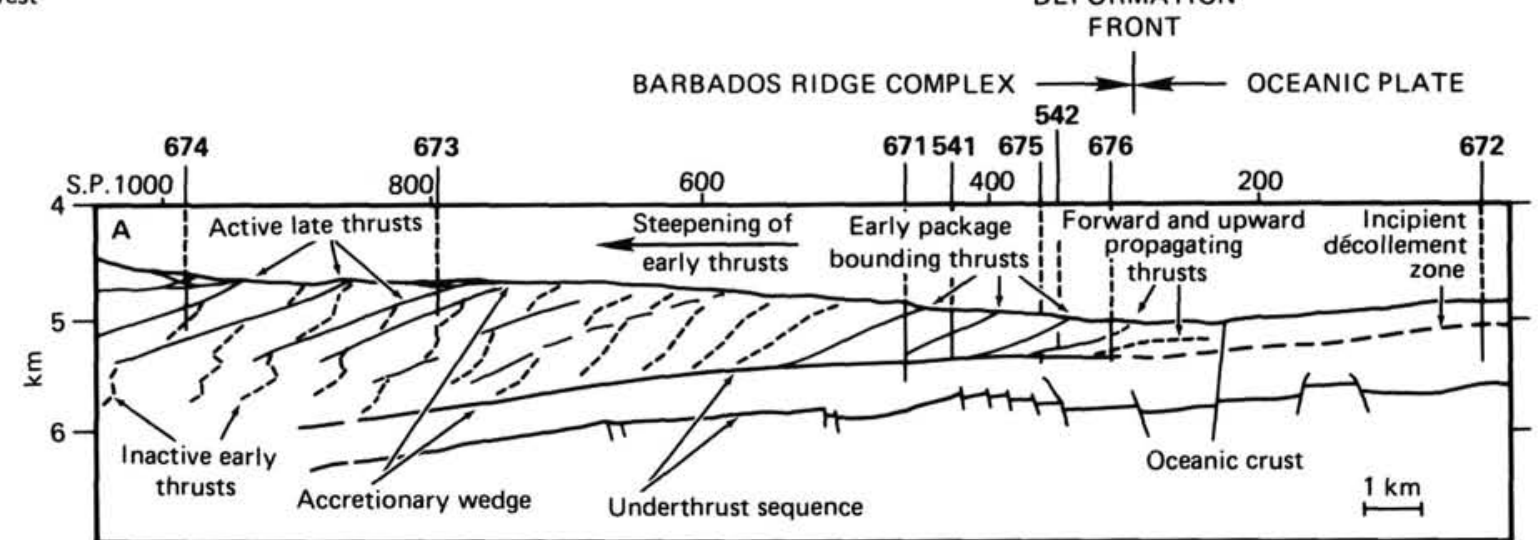

A

Vertical exaggeration $=2$

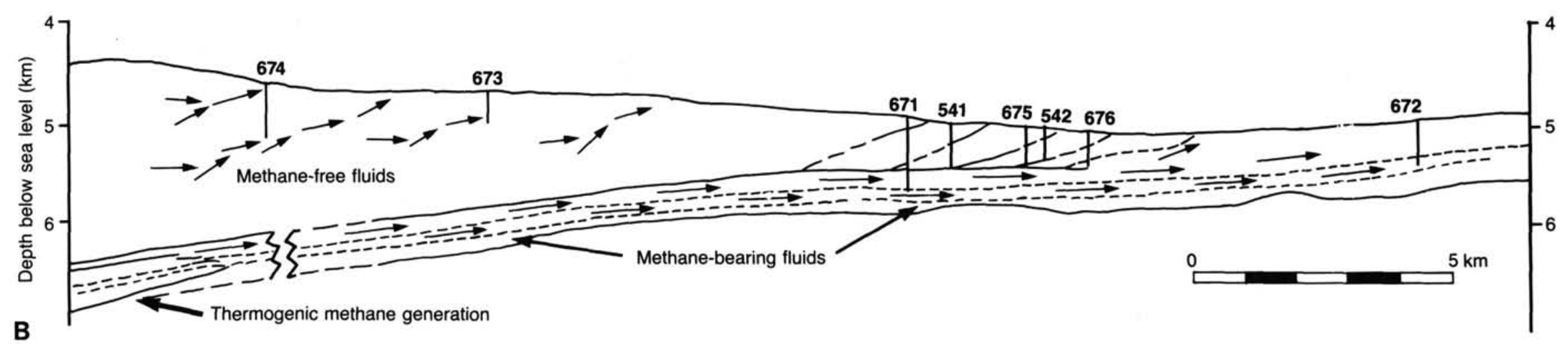

Figure 5. Overview of tectonics and hydrology of Leg 110 transect. A. Tectonic information. B. Suggested migration pathways for fluid expulsion. 


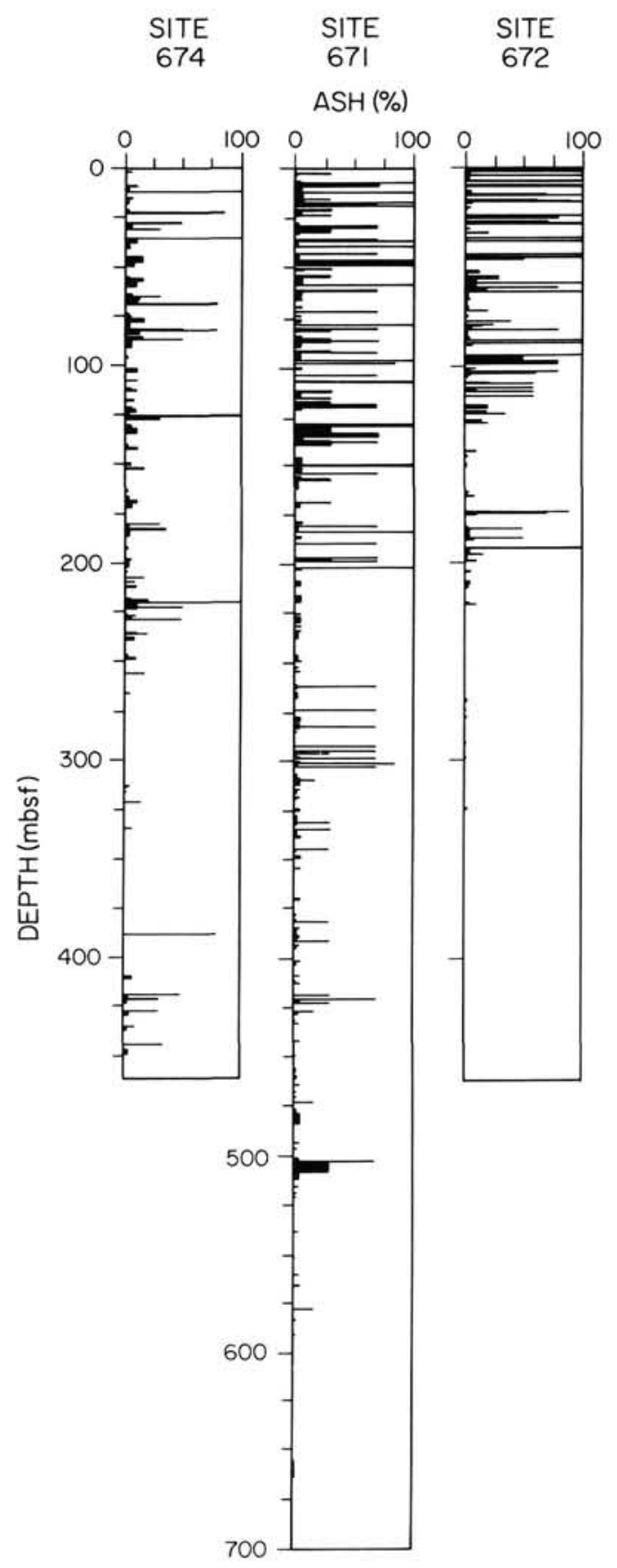

Figure 6. Ash distribution in Sites 672, 671, and 674 . 

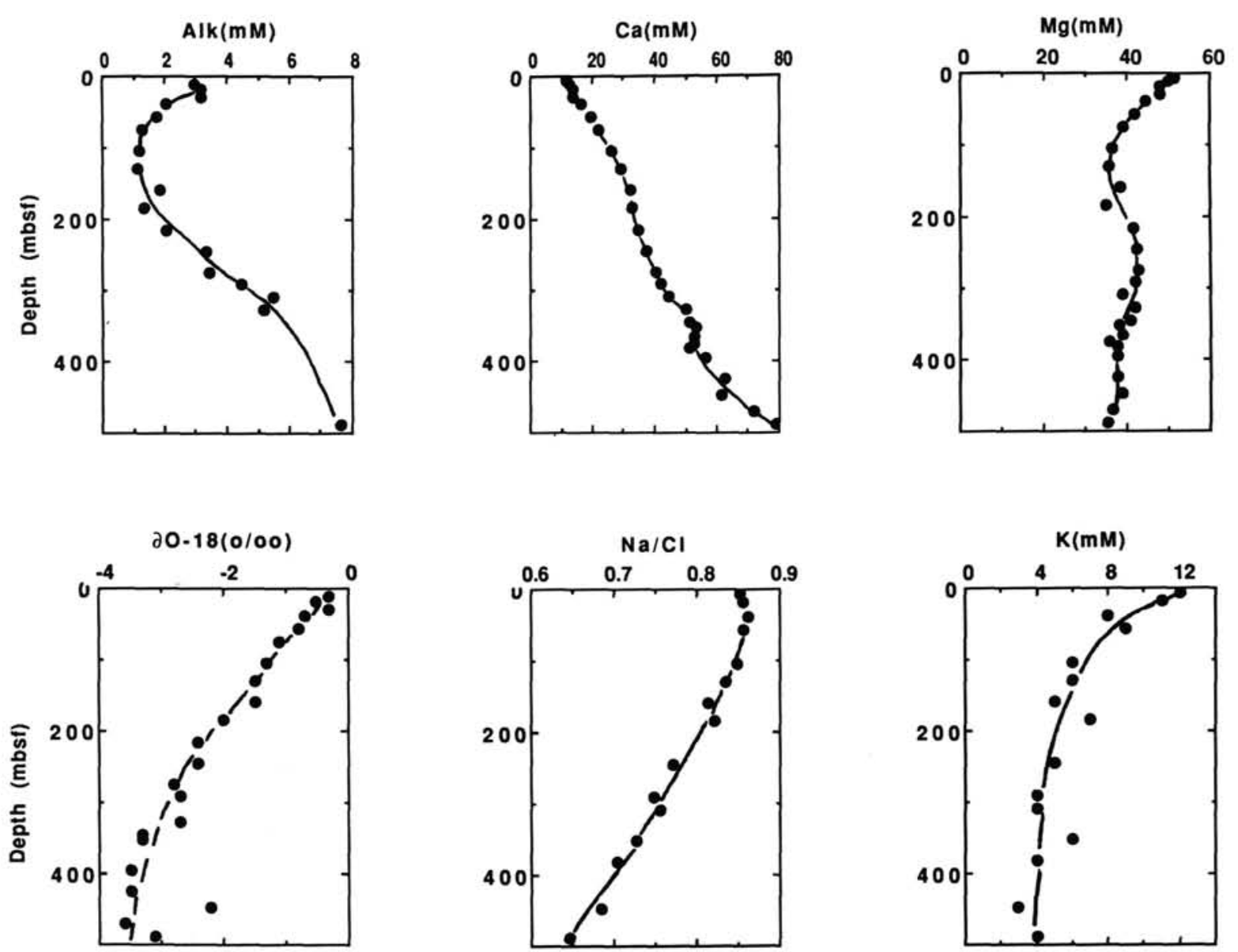

Figure 7. Interstitial water data for Hole $672 \mathrm{~A} . \delta^{18} \mathrm{O}\left(\mathrm{H}_{2} \mathrm{O}\right)$ on $\mathrm{K}$ SMOW scale. 

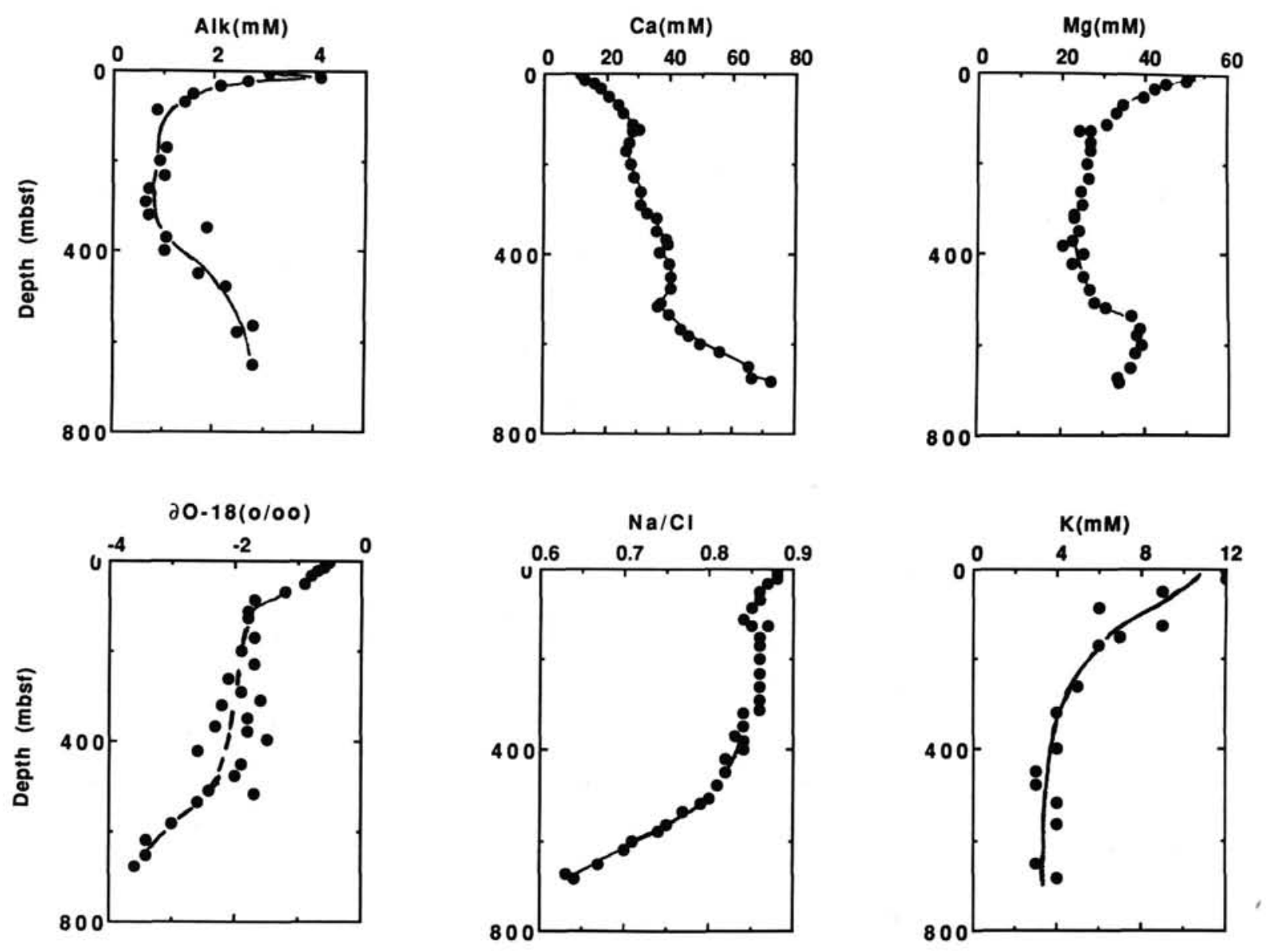

Figure 8. Interstitial water data for Hole $671 \mathrm{~B} . \delta^{18} \mathrm{O}\left(\mathrm{H}_{2} \mathrm{O}\right)$ on $\mathrm{K}$ SMOW scale. 

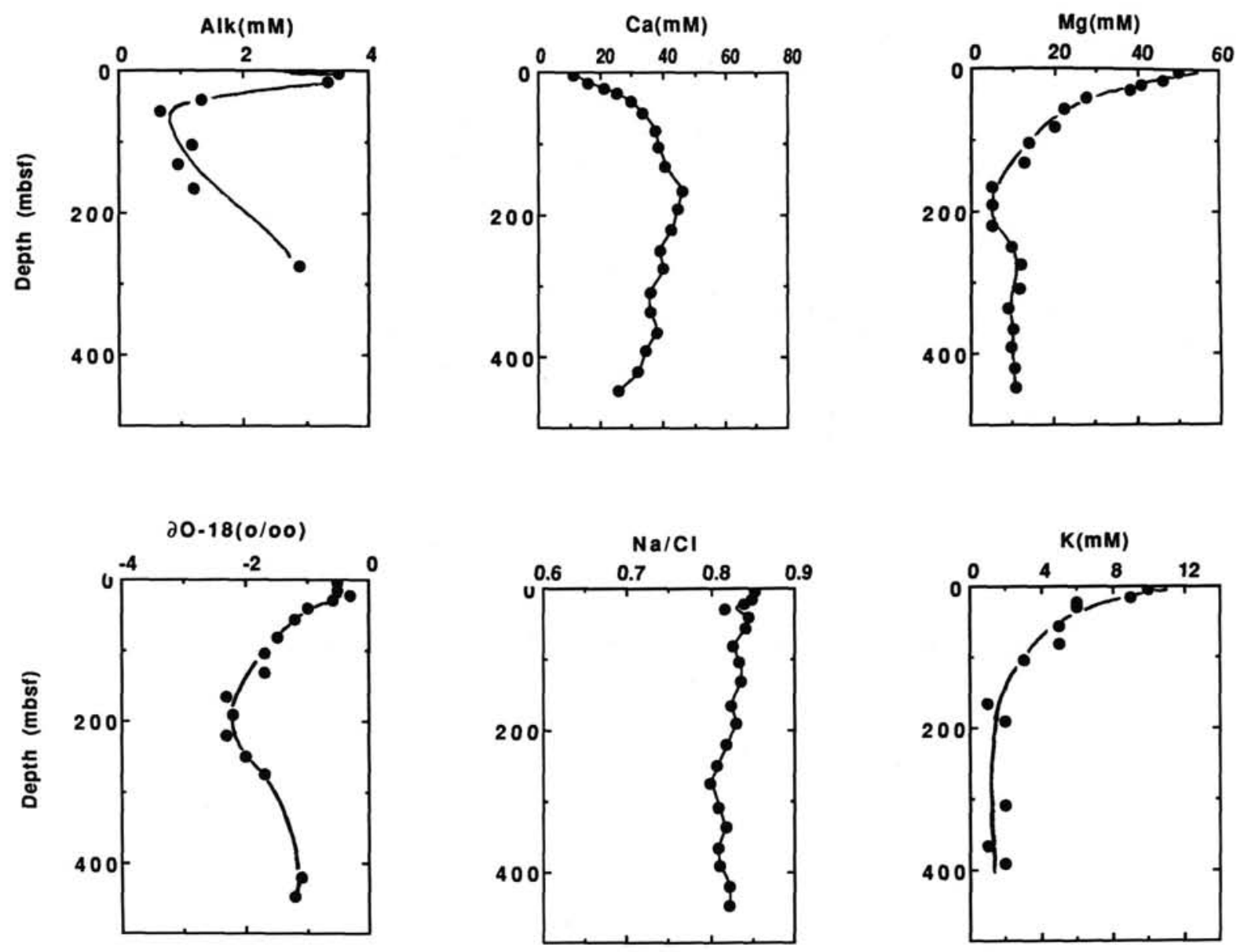

Figure 9. Interstitial water data for Hole $674 \mathrm{~A} . \delta^{18} \mathrm{O}\left(\mathrm{H}_{2} \mathrm{O}\right)$ on $\mathrm{K}$ SMOW scale.

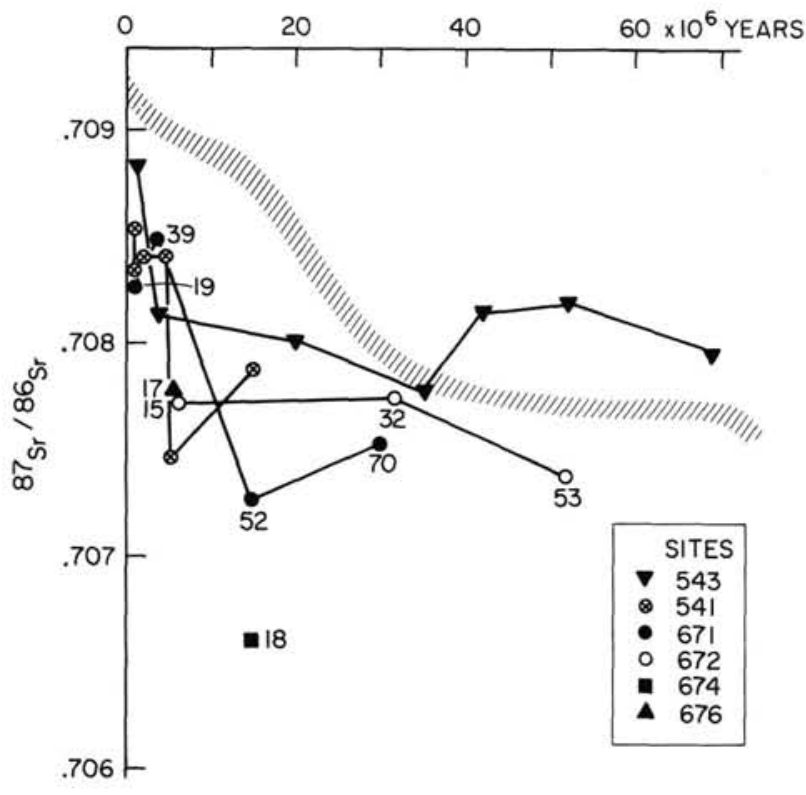

Figure $10 .{ }^{87} \mathrm{Sr} /{ }^{86} \mathrm{Sr}$ of dissolved strontium vs. age of sediment. Note lower than contemporaneous values in volcanic ash-rich sediments. Numbers indicate cores for each site. Hatched area shows contemporaneous seawater values.

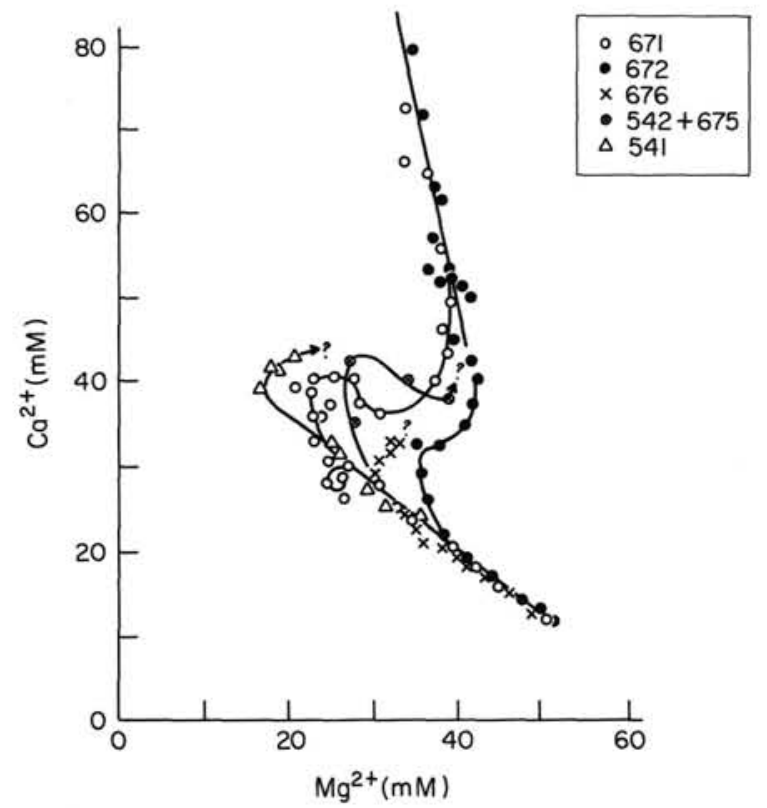

Figure 11. Correlation between $\mathrm{Ca}^{2+}$ and $\mathrm{Mg}^{2+}$ for Sites $671,672,676$, $542+675$, and 541 . 
J. M. GIESKES, P. VROLIJK, G. BLANC

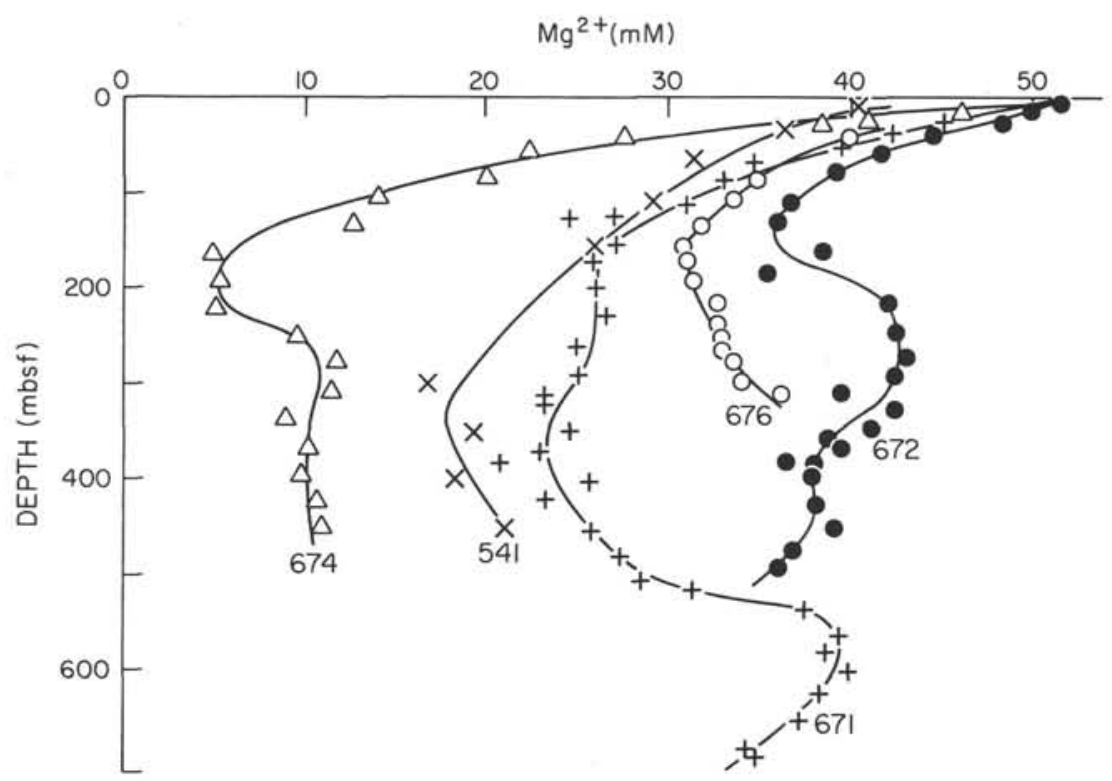

Figure 12. Composite profile of magnesium in interstitial waters from drill sites of Legs 110 and $78 \mathrm{~A}$. 